\title{
A recombinant vaccine targeting the parasitic ciliate Ichthyophthirius multifiliis
}

Jørgensen, Louise von Gersdorff; Kania, Per; Sepúlveda, Dagoberto; Lorenzen, Niels; Stratmann, Ansgar; Buchmann, Kurt

Publication date:

2019

Document Version

Publisher's PDF, also known as Version of record

Link back to DTU Orbit

Citation $(A P A)$ :

Jørgensen, L. V. G., Kania, P., Sepúlveda, D., Lorenzen, N., Stratmann, A., \& Buchmann, K. (2019). A recombinant vaccine targeting the parasitic ciliate Ichthyophthirius multifiliis. Poster session presented at 8th Congress of the Scandinavian-Baltic Society for Parasitology, Frederiksberg, Denmark.

\section{General rights}

Copyright and moral rights for the publications made accessible in the public portal are retained by the authors and/or other copyright owners and it is a condition of accessing publications that users recognise and abide by the legal requirements associated with these rights.

- Users may download and print one copy of any publication from the public portal for the purpose of private study or research.

- You may not further distribute the material or use it for any profit-making activity or commercial gain

- You may freely distribute the URL identifying the publication in the public portal

If you believe that this document breaches copyright please contact us providing details, and we will remove access to the work immediately and investigate your claim 


\section{A RECOMBINANT VACCINE TARGETING THE PARASITIC CILIATE ICHTHYOPHTHIRIUS MULTIFILIIS}

L. v. G. Jørgensen ${ }^{\delta 1}$, P. W. Kania ${ }^{1}$, D. A. S. Araneda ${ }^{2}$, N. Lorenzen ${ }^{2}$, A. Stratmann ${ }^{3}$ and K. Buchmann ${ }^{1}$

1 Laboratory of Aquatic Pathobiology at the Department of Veterinary and Animal Sciences,
2 DTU AQUA, National Institute of Aquatic Resources, the Technical University of Denmark

${ }_{3}^{3}$ W42 Industrial Biotechnology GmbH, Dortmund, Germany

Abstract

New vaccine candidates were identified targeting the one celled parasite Ichthyophthirius multifiliis, which negatively affects aquaculture freshwater fish productions all over the world. In silico selection with the use of artificial intelligence identified several potential vaccine candidates and three of these were recombinantly expressed using $E$. coli and insect cells. Following a vaccine trial one protein (a so-called neurohypophysial n-terminal domain protein, \#10) was found to indue moderate protection against 1 . mul of already known homologous protective antigen lag52b, which is a GPI-anchored cysteine rich surface protein. To be able to produce \#10 at low costs, recombinant expression has been conducted in an eukaryotic host. Puriffed presented in a virus-like conformation, which theoretically should be immunogenic to the fish.

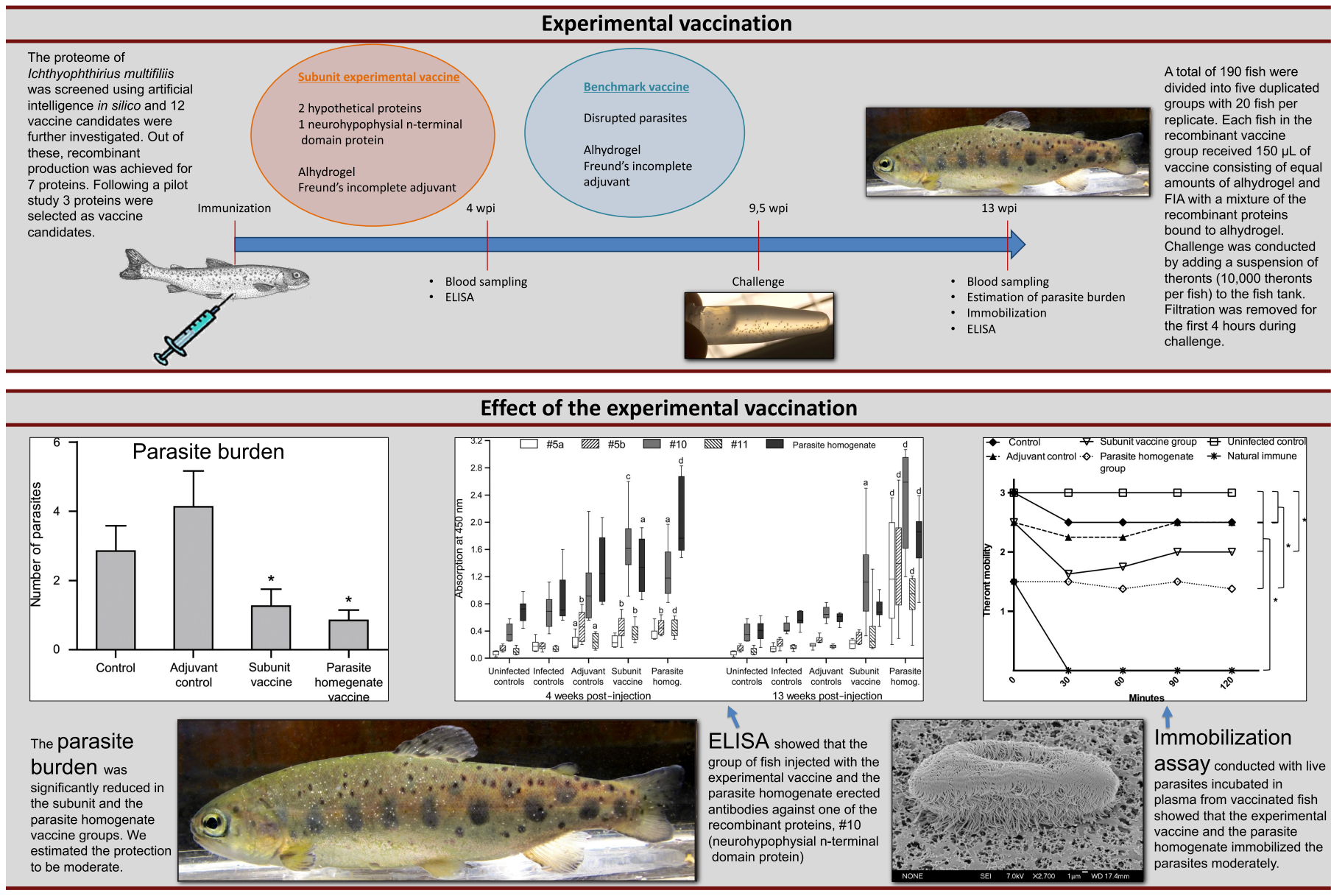

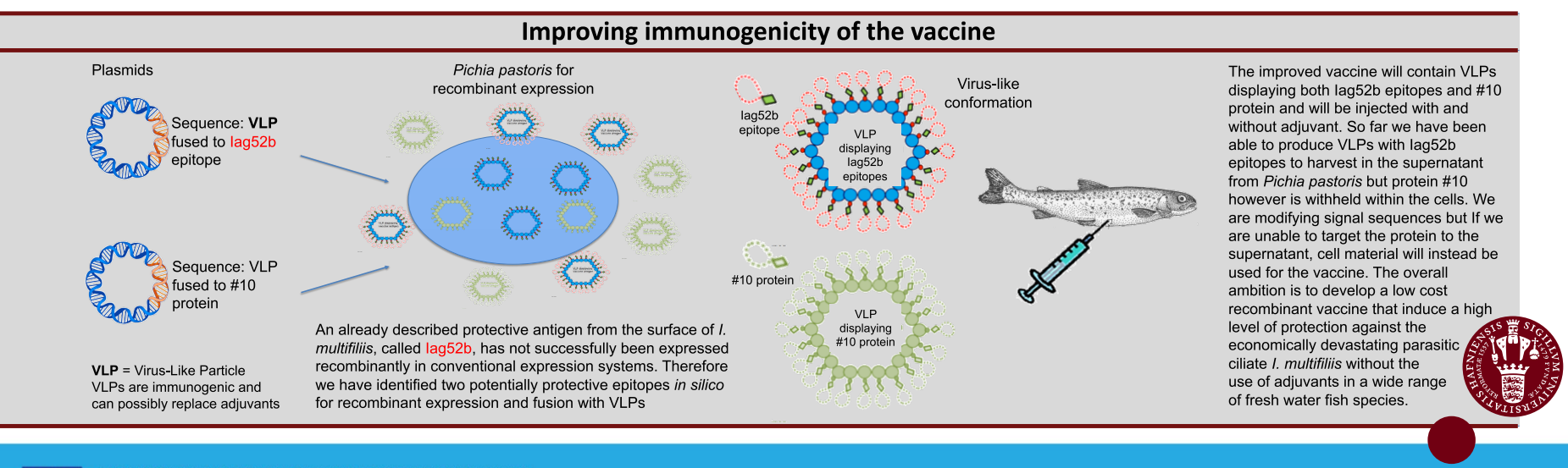

